This is a pre-print of an article published in the International Journal of Contemporary Hospitality Management. The final authenticated version is available online at:

Alegre, I.; Berbegal-Mirabent, J. (2016). Social innovation success factors: Hospitality and tourism social enterprises. International Journal of Contemporary Hospitality Management, 28(6): 11551176. https://doi.org/10.1108/IJCHM-05-2014-0231

\title{
Social innovation success factors: hospitality and tourism social enterprises
}

\begin{abstract}
Purpose - This paper aims at contributing to the existing literature on social enterprises and business model innovation. Particularly, it sheds some light on those factors that turn a social innovation initiative into a success, both in terms of meeting social needs and achieving economic sustainability.
\end{abstract}

Design/methodology/approach - By using a grounded theory approach, an inductive comparative case study is conducted. Two work integration social enterprises in the hospitality and tourism sector are selected. Both companies are located in Barcelona (Spain) under the same legal regulation and economic situation and initially run a manufacturing business. Due to the economic crisis they were forced to reinvent themselves in order to survive. Data was collected from different sources and coded using content analysis procedures.

Findings - Results indicate that three factors, named value proposition, appropriate market research, and stakeholder involvement heavily contributed to firm's success, corroborating previous studies. Furthermore, our study reveals that social need pressures and managerial trust on employees are additional factors that drive social business model innovation.

Practical implications - Changes in the demand, the rules governing the market, or economic downturns are external drivers for demand-pull innovations. In such context firms need to reformulate their business models if they wish to survive. Acknowledging the 
factors that help firms overcome these obstacles is of great interest for both academics and entrepreneurs.

Originality/value - Social innovation in business models is a topic still poorly defined in the literature, yet, its boundaries to other fields are still fuzzy. This paper aims to fulfill this gap by 1) presenting the theoretical domain in which this topic fits in, and 2) evidencing those successful factors that should be considered when designing and implementing a business model innovation which may help other firms facing a similar process.

Keywords - social enterprises, social business models, social innovation, hospitality and tourism sector

\section{Paper type - Research paper}

\section{Introduction}

Research on social entrepreneurship has gained increased attention in the last years spurred notably by the current fragile state of the global economy and the growing inequities and dilemmas that are threatening social cohesion. In this context, innovation plays a crucial role, lying at the heart of social entrepreneurs who seek business solutions to social problems (Chell, Nicolopoulou \& Karataş-Özkan 2010). Innovation is conceived not only as a vehicle to maintain competitive advantage in the marketplace but as the way to stimulate social change, contribute to growth and improve peoples' lives (Mulgan 2006).

Social enterprises that have supported innovation processes to create or readapt their businesses can be found in abundance and take the form of new institutions, organizational practices or structures (Austin, Stevenson \& Wei-Skillern 2006). Examples of innovative social enterprises cover a wide range of sectors, from microfinance (Battilana, Dorado 2010) to sustainable tourism (von der Weppen, Cochrane 2012). A social innovation takes place when a new idea establishes a different way of thinking and brings new approaches to old problems enacting institutional change to existing standards. These initiatives refer to intended actions where the primary concern is about generating societal value rather than wealth (Bessant, Tidd 2007).

Although the paradigm of social innovation is attracting increasing attention among practitioners and policy makers, it is still a nascent field of research with very little formal evidence (Pol, Ville 2009). Recently, social entrepreneurship has been linked to social 
innovation (Harvey et al. 2011), but there is also scarce literature on how social innovation processes take place in such enterprises and what are the key factors that contribute to this process.

Given the limited theory published and considering the essential role social enterprises are called to play in today's world, in this paper we aim at investigating those factors that make social innovations turn out into successful outcomes, both in terms of meeting social needs and achieving economic sustainability.

To this end an inductive comparative case study method was chosen (Eisenhardt 1989). We compare two social enterprises that, through innovation, enter into the tourism and hospitality management sector. Both cases are work integration social enterprises (WISE), a category of social enterprises that train disadvantaged people with psychological, social, or physical disabilities in order to permanently integrate or reintegrate them into the workplace (Borzaga, Solari 2001). We carefully selected the cases to minimize exogenous variation; both cases are located in Barcelona, Spain, and both of them initially run a production business. We collected data for this study from interviews, archives and publicly available data. Data from different sources were coded using content analysis procedures. Due to the economic crisis, both WISEs, named Icaria and Pila, were forced to reinvent their business in order to survive. Icaria founded a Youth Hostel while Pila, taking advantage of Barcelona's high number of tourists, started producing handmade souvenirs. Icaria's change was successful however, Pila is struggling to survive. Analyzing the difference between both innovation processes will shed some light into business model innovation in the social arena.

This research aims to contribute to the social enterprises and social innovation literature by using a grounded theory approach to two cases in the hospitality and tourism sector. Investigating which are the main factors that turn a social innovation initiative into a success or a failure is of interest for both, entrepreneurs and academics.

This paper is organized as follows. Next section underlines the theoretical background concerning social enterprises and business model innovation. Then the methodology is outlined and the cases are presented. In the discussion section the cases are compared and finally, findings and conclusions are highlighted. 


\section{Social enterprises and business models}

It is widely accepted that innovation has become a requirement to achieve business sustainable success. Indeed, innovation processes and mechanisms have attracted much attention in the literature (Sawhney, Wolcott \& Arroniz 2011). However, little attention has been paid to the social dimension of innovation, despite it represents an effective, efficient and sustainable way of responding to existing problems.

When social innovation is taken into account, the value created accrues primarily to society (as a whole or to specific groups) rather than private individuals (Phills, Deiglmeier $\&$ Miller 2008). Said differently, triggers for social innovation are not only new products or ways of operating, but different ways of thinking and acting that lead to changes in current paradigms and bring up a social change (Cajaiba-Santana 2013, Dawson, Daniel 2010).

Social innovation is therefore conceived to transform markets towards sustainable development (Boons, Lüdeke-Freund 2013). It is in this transformative power where business models come into play.

The origin of business models can be found in data processing and management of IT systems (Konczal 1975). From then on, academics have approached business models and their components in a number of ways. Although previous research converge in declaring that business models represent a source of new value creation and potential competitive advantage (Chesbrough 2010, Chesbrough, Rosenbloom 2002, Johnson 2010, Markides, Charitou 2004, Mitchell, Coles 2003) acting as a driver for firm performance (Rajgopal, Venkatachalam \& Kotha 2003), there is a lack of consensus on the theoretical grounding behind the definition of what a "business model" is (Zott, Amit \& Massa 2011).

Insert Table 1 about here

From this table it can be inferred that business models offer a consistent and integrated picture of a company describing the rationale of how an organization creates, delivers and captures value. However, for this purpose being accomplished, it is necessary to identify the elements and relationships that describe how the business operates. This elements or components have also been addressed in previous studies and have been 
conceptualized differently according to their nature (Shafer, Smith \& Linder 2005), as shown in Table 2.

Insert Table 2 about here

A second debate in the business model literature has its foundations in the static character of these instruments (Baden-Fuller, Morgan 2010, Demil, Lecocq 2010). According to Teece (2010), the ideal business model rarely appears in the initial stages. Indeed, empirical evidence suggests that ventures that are more likely to succeed are those that do not have a perfect business model template but a flexible one that allows the introduction of readjustments. To this end, new dimensions have been added so that they capture changes in strategy or the evolution of the model. Trial and error, experimentation, reinvention and adaptation are some practices that attempt to respond or anticipate changes or constraints in the firm's environment (Afuah 2004). For instance, (Sinkovics, Sinkovics \& Yamin 2014) add two components to the business model canvas designed by (Osterwalder, Pigneur 2010), namely change in offering and change in strategy.

More recently, definitions of business models have also incorporated the concept of social value creation, which is closely related to social innovation and, by extension, to social enterprises (Easterly, Miesing 2007, Stoner, Wankel 2007).

The primary objective of social enterprises is to address areas of unmet social needs by creating both social and economic value rather than making a profit for their stakeholders (Nicholls 2006). They operate by providing goods and services in an entrepreneurial and innovative fashion, using profits to attain social purposes (Mair, Martí 2006, Thompson, Doherty 2006).

Sustainability of social enterprises depends on their ability to cover full costs from their operations and their competency to establish a market share. Unlike traditional enterprises, the premise is to develop self-sustaining instead of profit maximizing businesses. This means that there are no dividends for the shareholders (Yunus 2008). Surpluses generated are reinvested in the business aiming at improving the service or scaling up the organization. 
Remarkable achievements of companies like Grameen Bank, Aravind or Brac, have fueled the interest among academics on those success factors that are found to act as drivers of social innovation and guarantee the sustainable development of firms.

Literature on social enterprises business models gives us some clues in this regard. According to Thompson and MacMillan (Thompson, MacMillan 2010) social enterprises business models should not exclude a profit orientation, but the emphasis should be more oriented towards generating social change. This duality of goals stresses the need for adjustments in traditional business models (Michelini 2012). A specific business model framework for social enterprises is therefore needed in order to articulate both the social and the economic profit equation.

Despite the growing importance of these new approaches, literature is still lacking (Michelini, Fiorentino 2012). Nevertheless some developments can be found. For instance, Mair and Schoen (2005) refer to Hamel's (2000) components of the business model to analyze social businesses.

Going a step further, Yunus et al. (2010) suggest a basic framework which includes four elements only: value proposition (who the customers are and what is the perceived value of our offer), value constellation (how the offer is delivered to customers), economic profit equation (how revenues are generated and the cost structure), and a social profit equation (how the company generates social benefit in terms of risks and benefits). In this configuration it is worth noting the importance of the value proposition and value constellation in considering not only the customer but to expand it to all stakeholders in order to involve and engage them in the social mission of the project (Márquez et al. 2010).

Other developments include the theoretical model proposed by Michelini and Fiorentino (2012), which is built on the basis of the former framework (Yunus, Moingeon \& Lehmann-Ortega 2010) and that includes four areas, namely offer (value proposition), eco-sysem (governance model, value chain, competences and partner network), market (market segment and distribution) and economic features (revenue management).

The analysis of business models from social enterprises would undoubtedly help us identify common patterns followed that lead the companies to succeed. Previous works provide some insights in this direction. Particularly, previous studies have underlined the important role of the founder. In this sense, the founder's individual traits and vision are 
essential in defining the leadership style (Drayton 2002, Bornstein 2004, Mair, Schoen 2007).

Essential success factors also include customer and market awareness. Becoming a trusted brand is a direct route towards business success (Allan 2005). For social enterprises it is however a really challenging goal because components of the business offer such as the price and the offer itself can be constrained due to the nature of the business. However, they benefit from clearly specifying the social mission as a way to raise awareness of the value they are providing to the community.

Likewise, the involvement of stakeholders is a key factor. As pointed above, social business models stress the importance of considering not only customers, suppliers and other partners, but also any shareholder able to understand and accept the social mission of the venture (Yunus, Moingeon \& Lehmann-Ortega 2010). Integration and an active involvement are therefore crucial.

Value networks and complementary partners have also been proved to facilitate social value creation (Mair, Schoen 2005). Finding the correct partners is a highly timeconsuming and demanding task, however, partnerships with collective objectives may help to open up the business and gain access to new resources, generating knowledge spillovers which in turn may lead to a broader offer portfolio. Cooperation and exchange of ideas and values between public, private, and nonprofit sectors are shown to be highly productive and low in risk, becoming a major factor of success.

Social enterprises should also possess a high innovative potential. They should be able to challenge conventional wisdoms and design new strategies which modify the rules of the industry. Thus, undertaking continuous experimentation is crucial in order to envision new ways of doing things (Yunus, Moingeon \& Lehmann-Ortega 2010). The lean approach and the notion of the Minimal Viable Product (MVP) introduced by Ries (2011) might be useful in this context. Learning from short cycles and employing a regimen of continuous improvement helps minimize risk and maximize the firm's rate of learning.

Lastly, the success of any social enterprise relies on maintaining a balance between the social mission and the profit (von der Weppen, Cochrane 2012). Although their organizational structure is based in a no-loss, no-dividend basis, social enterprises are different from charity and ONGs organizations (Yunus, Moingeon \& Lehmann-Ortega 
2010). This means that the managerial mindset must include the primary purpose of serving society, but without forgetting that to achieve this goal firms need to recover their full costs so they can be self-sustainable.

\section{Methodology}

To really understand the business model of a company it is necessary to conduct a detailed analysis of its structure and organization, therefore an inductive multiple case study method was chosen (Eisenhardt 1989). The setting of the study are work integration social enterprises (WISE). Work integration social enterprises are a category of social enterprises that train disadvantaged people with psychological, social, or physical disabilities in order to permanently integrate or reintegrate them into the workplace (Borzaga, Defourny 2001).

Social enterprises are private organizations that adopt business strategies to achieve socially-oriented purposes (Dacin, Dacin \& Tracey 2011). Although in many countries WISEs receive subsidies from government or donations from institutions, their main source of revenue generation is selling products or services in the market.

Spain, together with France, is one of the European countries with a major number of work integration social enterprises (Spear, Bidet 2005); many of them were created in the 60's when no institutional support was in place for people with intellectual disabilities. Groups of parents with children with intellectual disabilities as well as sensible professionals started different companies to provide jobs to this people. At that moment people with intellectual disabilities were marginalized and the common believe was that they should stay at home and that they were not able to work. Work integration social enterprises were at that time a big social innovation, offering people with intellectual disabilities a decent job with a proper salary and, through work, offering them the opportunity to be an active part of society. Most WISEs, constituted as non-profits, do not seek great financial performance, neither competitive advantage. Sufficient financial results that allow the company to increase or maintain the number of jobs is enough. In Spain, the economic crisis that started in 2008 has forced governments to drastically reduce the amount of subsidies that were given. In addition, demand has fallen and Spanish unemployment has become the highest in all European countries. This situation has strongly affected the commercial performance of all companies in the country, but specially 
WISEs that have seen how subsidies were reduced, sales were falling and, at the same time, social demands for employment were increasing.

Studying WISEs at this particular point in time is a very adequate scenario for the present research. The Spanish economic situation over the last 15 years before the global crisis started in 2008 was extremely good, with a 3 to $5 \%$ yearly GDP growth. WISEs, as most companies in the country, were able to achieve good financial results which enabled them to grow and create more jobs. However, when, due to the economic crisis, profit and revenues decreased dramatically, the tension between the need of having positive financial results and the willingness to maintain or increase the number of jobs for people with intellectual disabilities grew and forced WISEs management to react.

Innovation within business models can be manifested in three different ways. First, business models, by themselves, can be considered as innovations. There is no need to modify the core product/service, but to introduce small changes in the internal process which may improve firm's efficiency (Mitchell, Coles 2003). Second, firms can also innovate following a demand-push approach, which entails improving or broadening the current portfolio offer in order to maintain leadership in the market. These variations may encompass little changes in the business model, and can be the key to the renewal of the business. Lastly, there is also the demand-pull approach, where business models should be reformulated to fulfill new customer needs and business environments (Teece 2010). For the purpose of this paper we focus on this third type of innovation.

Several work integration social enterprises were visited and a preliminary report was written to identify two of them to study more in depth: Icaria and Pila. Both of them decided to react to the crisis with a business model innovation in the tourism and hospitality sector, which is the object of the present study.

We carefully selected the cases to minimize exogenous variation; both cases are located in the same city of Spain, Barcelona, under the same legal regulation and economic situation and both of them initially run a manufacturing business.

Icaria had originally a printing business with approximately 40 employees. As a reaction to the crisis, Icaria founded the first Youth Hostel in the World managed completely by people with disabilities. Icaria employs now more than 100 people with disabilities and has won numerous prizes for their innovative initiative. 
Pila originally had an assembly shop with approximately 30 employees. In 2008 started a new business based on the production and commercialization of souvenirs for tourists. The business did not work well and Pila is now struggling to survive.

A brief summary of the main characteristics of each of the two companies analyzed is summarized in Table 3.

Insert Table 3 about here

Data were collected using several data sources: (1) Interviews with the CEO and other members of the management team in each of the companies, (2) webpages of the companies, leaflets, press releases and yearly reports, (3) site visits and observations and (4) interviews with key informants like the government responsible for WISEs subsidies, clients and suppliers. In addition to the information on the particular companies, information on the sector was acquired in fairs and social entrepreneurship conferences.

Data were gathered during a period of one year (2010). The interviews were semistructured and lasted between one and two hours for each of the informants. The questionnaire that served as guidance for the interview contained questions about the background of the manager, history of the company, how the company manages the social and the economic objective and how do they measure their social and economic impact. Following previous literature (Merton, Fiske \& Kendall 1990), data collection was considered complete when three conditions were met: (1) successive enquiries provided no additional relevant information; (2) information was triangulated by at least two different sources of information; (3) analysis of data from different sources provided a reliable, consistent, and unique interpretation of the phenomenon under analysis.

All interviews were recorded and transcribed. Approximately 250 pages of written documentation were collected. Analysis of the data was conducted using a two-step process whereby descriptive case reports were prepared for each WISE under investigation (Eisenhardt 1989), and then a cross-case analysis was developed (EISENHARDT, GRAEBNER 2007). Descriptive coding was used to identify theoretical constructs (Miles, Huberman 1994). Atlas.ti was the software used for the codification process. Three 
researchers performed independently the descriptive coding and levels of intercoder reliability were higher than 0.8 (kappa>0.8) for all codes (Hruschka et al. 2004). Codes were based on previous literature. For example, a paragraph or sentence was coded as "innovation" if it describes the production or adoption, assimilation, and exploitation of a value-added novelty, renewal or enlargement of products, services or markets, development of new methods of production and establishment of new management systems (Crossan, Apaydin 2010).

\section{Icaria}

\section{Background}

In 1976 a group of motivated teachers, led by one of them, started a special education school, a school for children with mental disabilities, in Barcelona. The school, called Taiga, was small but successful but the founder quickly realized that, once school was finished, those children, now young adults, had great difficulties to find a job.

For that reason in 1992 they decided to start a printing studio. They bought the machines and rented the facilities necessary to print all type of documents like leaflets or posters, but also other materials such as t-shirts or anything necessary for an advertising campaign. The employees of the printing studio were alumni from Taiga School.

Although the school and the printing studio were run independently, an organization was created to coordinate both, the name of which was Icaria.

The printing studio was successful many years and provided enough work to provide jobs to all the students that were finishing Taiga school. Many institutions became loyal customers of Icaria printing studio and ordered their leaflets and official communication documents to the work integration enterprise. In response, the printing shop offered a high quality product, the flexibility of accepting small orders and the convenience to be close to the client. But with time, the printing industry became every day more technological and less workforce was needed to produce the same quantity of output. It was necessary for Icaria to invest in new machines to keep up to the industry standard, maintain the good quality and be able to serve the new customers' requirements. In addition to that, 
globalization moved some customer orders to lower income countries, where cheaper prices were attractive for some promotional printed products.

New machines were too expensive for Icaria but, in addition to the price, investing in automated processes that needed less workforce did not make sense for a company that was put in place precisely to provide jobs to people with certain difficulties to find one in the standard job market. Not investing in new technology had an effect on the amount of orders Icaria received. The number of orders and clients declined and in mid-2000's the situation was critical.

\section{The crisis}

The orders declined, many clients were lost but Taiga school was still functioning and generating around 10 young adults ready to enter in the job market. Spanish unemployment was rising and finding a job, for a young person with mental disabilities was extremely difficult. Therefore, the objective of the printing studio, to provide jobs to people with disabilities, was more necessary than ever. The pressure experienced by Icaria management team was twofold, in one hand they felt the need of generating around 10 new jobs every year and, on the other hand, the revenues of the printing job were decreasing every day.

"We used to receive thousands of t-shirts from China, ready to print at our facilities but now the t-shirts arrive already printed. Our orders are now of hundreds of products instead

of thousands, but our personnel cost is the same!. The worst thing is that in our school, Taiga, new groups of students are being trained in printing and will be soon ready for their job at the printing job. What are we going to do?"

\section{MJP. Founder of Icaria.}

Investing in technology to update the printing studio operations was not an option because this would decrease the number of workers needed. As said before, at the same time, new students were finishing the Taiga school and needed a job. There was only one way to go: create a new business that could provide jobs to those that were coming out of school and to those that were not any more needed in the printing shop because of the volume decrease. 
"We knew we had to do something new and the service sector seemed attractive, services are difficult to offshore!. We were very open about what could be done, anything would be ok as long as it allows us to provide jobs to our boys"

\section{KS. Icaria Management team.}

The new business had to fulfill two important requirements: (i).- be job intensive, as the main objective of the organization was to provide jobs for people with disabilities and (ii).difficult to move to low-income countries and not extremely dependent in technology, for, in the future, not having the same experience they had with the printing studio.

One day, through some friends that had recently travelled to Switzerland, the general manager learned about a small hotel that was run by people with disabilities in a small rural Swiss village. Why not a hotel? The next step was to go and talk with the local government. The local government fully supported the idea and suggested to start a Youth Hostel, as the city of Barcelona was underserved in terms of youth hostel rooms. The local government also had a building, which had been a school before, that put at Icaria's disposal with a long term contract and a minimal rent. Icaria management team went to Switzerland and visited the small hotel that, although very different from a big urban youth hostel, gave them some good ideas. They also had the support of some important and big Barcelona hotels. For example, one big luxury hotel that was renovating some of its furniture gave the old one to Icaria for free. With the idea, the building, and the support from the local industry and government, Icaria management team started the youth hostel Inout.

\section{The youth hostel}

Inout Youth Hostel offers 200 beds in rooms of 4, 6 or 10 beds. It also has a restaurant for both clients and non-clients. 99\% of the employees of Inout Youth Hostel have a disability, most of them a mental disability. Employees with mental disability take care of the garden, the cleaning services, restaurant and many other activities involved in efficiently operating a youth hostel.

Inout belongs to the main industry associations like the International Youth Hostel Association or HostelWorld.com. It also has partnered with the Sustainable Tourism program of the Barcelona local government and is part of the Global Compact program of the United Nations. It has received many prizes among which the Responsible Tourism 
Prize of the Catalan Government 2013 and the 2010 Hostelworld Worldwide Special Contribution Winner.

It is located 20 minutes by subway from the center of the city and it offers clean rooms at a good price, restaurant, nice surroundings and a pool. Its clients are mostly young people but also families that visit Barcelona and look for a convenient place to stay. Clients are highly satisfied, as it can be observed in tripadvisor recommendations like the following one:

"I took a school group to this hostel and had a fantastic time. The rooms were spotless and spacious. The location was beautiful and a convenient train journey to the centre.

We had evening meals which were excellent value and very tasty. The location is beautiful surrounded by pine forests but just minutes from the metro.

The thing that stood out was the care taken by the staff to look after us. As an example one of our group had left a camera on the train. The guy on reception took time to sort this out phoning lost property with the details. On our final day as we were sitting down for our meal a few hours before leaving for the airport we received an email that the camera had been located I went in to the centre to pick up the camera, when I met the group again my meal had been packed up for me to eat at the airport."

Visitor from Liverpool. Reviewed February $11^{\text {th }}$, 2014 in tripadvisor.com

\section{The change}

Table 4 illustrates the change that Icaria was able to make. Although the printing studio is not completely closed, most employees from the printing studio have been transferred and are now working at the hotel. The hotel is growing and improving its facilities which gives room to incorporate new students coming from Taiga school.

The change has not been easy. Icaria management team had no previous experience in the industry and had to learn everything from scratch. Support from institutions and training and help from other hotels were a key factor to Inout's success. Acquiring new clients was also a very challenging endeavor. The printing studio had a business to business (B2B) structure while the hostel is a business to customer (B2C). Most sales are done through the internet. 
There are many work integration social enterprises in Spain, but very rarely in the hospitality and tourism sector where people with disabilities have to deal with clients. This poses many questions to Icaria's management team. They had to train their employees to deal directly with customers and specifically with international customers. But the question about how the visitors would confront to be in a place run mostly by people with disabilities was unknown until the hostel opened its doors. They decided not make the social aspect of Inout their main selling point, but not to hide it either. From the 32 comments that Inout hostel has received in tripadvisor.com so far, none of them refers to the social aspect of Inout while most of them write about the surroundings, cleanliness of the rooms or good service of the staff.

Insert Table 4 about here

\section{Pila}

\section{Background}

Pila started in 1968 as an association of parents with children with mental disabilities. It started as a support group, to help each other and organize leisure activities together. It was not until 1991 that the same group of parents, led by one engineer, decided to start a business to provide jobs to their disabled children, at that moment already young adults. As most work integration social enterprises at that time, they started an assembly shop where they assembled products from other companies. Initially they accepted all type of orders like assembling promotional packs or putting together Christmas lots, however, as time passed by, they specialized on the assembly of electrical components. In the same area where Pila was located there was a company that produced and sold small electrical appliances and part of the assembly process, which was difficult to automatize, was done by Pila. This was their main client which accounted for approximately $80 \%$ of the volume that Pila assembled.

Pila employed not only the children from the parents that belonged to the founding team, but also some other people with mental disabilities from the area. Most of these new 
employees were on their forties when started working in Pila and that raised another issue among Pila founding team. Some of the employees had quite old parents that due to their delicate health could not take care of the quite intense care that a person with disabilities needs. In some cases, the parents of the employees died and the employee had no other family members or relatives that could take care of them. For all that reasons Pila association decided to open a residence or retirement home where employees that could not live with their family could find a home. The residence was run by Pila but fully subsidized by the government.

Until mid-2000's Pila association successfully run the residence and the assembly shop.

The crisis

Pila's main client, as many other Spanish companies, was also affected by globalization and by the economic crisis and its sales started to decrease, that, in turn, affected Pila and its assembly shop.

Pila's general manager was worried about maintaining the jobs that were in place:

"We need to do something urgently, we hardly cover costs right now. I still have some buffer because I can send 3 or 4 employees to early retirement but still, it is necessary to create alternatives to our traditional business"

\section{JIM. Founder of Pila.}

People with mental disabilities, with age, loose abilities faster than others. That is why, depending on the degree of disability and the age, they can go to early retirement at an earlier age that people without disabilities. Given the age of Pila's workers, this gave Pila a small buffer to reduce the number of employees. They would probably not have to lay off anyone in the short term, they would just retire some of the eldest employees. But still, the management team knew they had to find a solution in the long term.

They heavily relied in one client, which was certainly a problem, but Pila's management felt they should make an important change in their business, more than just acquiring some more clients. Assembly was a low-cost low-value-added activity and the risk of their clients moving the assembly to other countries or to automatized the processes 
was high. It is true that they offered the possibility of doing small orders and a lot of flexibility but probably that was not enough to maintain and grow the business.

According to Pila's management team, the new business had to fulfill some important requirements: (i).- produce their own final product, to produce something more value-added and less dependent on a single client; (ii).- not related with the industry, as they felt the crisis was very strong in this particular sector but more related to the service sector like tourism, that in Barcelona was strong and not very affected by the crisis and (iii).- able to be performed by their employees. This third requirement constraint the array of options that Pila could think about as the management team concentrated on finding a new business in the area of assembling or manufacturing because Pila's employees had experience and knowledge in handmade jobs.

\section{The souvenirs}

One of the social workers that was employed at Pila had also studied arts and was skilled in working with pottery. She created nice pottery figures and jewelry (necklaces, earrings and bracelets) made by ceramic pieces. She proposed to Pila's management team that they could start producing pottery and, specifically, souvenirs for tourists made with pottery. Producing and selling ceramic souvenirs fulfilled Pila's requirements for the new business: working with pottery was still a job that required manual skills, with is what Pila's employees had experience and knowledge on; it was related with the tourism industry, quite big in Barcelona, and finally, it was a final product that could be sold on many different

places and therefore finishes with the high dependence on a single client that they had until now.

The idea was presented in the annual meeting of the association, that reunites the families of all Pila's employees. The families, that trust the general manager, accepted the idea.

\section{The change}

Pila bought two industrial ovens to bake the pottery and started the production. They did not stop the assembly shop but some of the employees that were no longer needed for the assembly because the volume was lower than before, were moved into the new business and received a small training on how to work with pottery. 
The process starts with the raw clay that is modelled and then introduced in the oven. Once cooked the piece is painted and decorated and finally, if needed, is assembled and packaged.

Once the first pieces were made, the general manager went to see several potential clients like tourism offices, museums, monuments or churches that often have a small souvenir shop. Some of them accepted to sell Pila's souvenirs but sales were not as high as expected. Many souvenirs were made in low-income countries and therefore Pila's prices were out of the standard price range for a souvenir.

The change in Pila, summarized in Table 5, was not successful. Souvenir's sales were nearly insignificant. Pila tried to leverage the social component of it by putting a sticker on the back of the pieces signaling that the product was made by people with disabilities and with ecological materials and processes but still, the claim did not help increase sales. According to Pila's management team their main problems were not to have any sales and marketing experience in the tourism sector, their lack of knowledge on how to position the product, where the most appropriate places to sell it were and also what was their competition and the appropriate price range.

Insert Table 5 about here

Pila, from the souvenir's production, was not able to generate enough revenues to cover costs and, at the end of 2013 was struggling for its survival.

\section{Discussion}

Icaria and Pila cases were chosen because of their initial similarities but their divergent outcome. Both companies were work integration social enterprises dedicated to manufacturing labor, one in printing and the other in assembly. Both decided to innovate to increase their revenue generation and, as a consequence, increase or maintain the number of jobs for people with disabilities. However, one of them (Icaria) achieved the proposed objective while the other did not. Analyzing the differences between both scenarios can 
shed some light in what factors influence success in social business model innovations, a field still under-researched. The most relevant differences identified are five: value proposition, market research, stakeholder involvement, social need and managerial trust on employees. The first three: value proposition, market research and stakeholder involvement, had been already identified in the literature while the latter, social need and managerial trust on employees, constitute the main contribution of our paper.

\section{Value proposition}

Icaria offers a comfortable, cheap and clean place to stay at less than 20 minutes by metro from Barcelona city center. In addition to the stay, the youth hostel has a garden and a swimming pool for clients and a restaurant with good and affordable Mediterranean food. Their value proposition is clear and unique in the city. There are not many hostels at an affordable price in Barcelona and even less with garden and a swimming pool. The comments and reviews that the hostel receive in several webpages increase the hostel reputation and reinforces its value.

In contrast, the value proposition of Pila's souvenirs is not really clear. The fact that the souvenirs are made out of pottery does not add a tangible value to the product and makes price higher. Barcelona shops are full of souvenirs, most of them produced in developing countries, therefore very price competitive. The niche of luxury pricy souvenirs is small and the design and quality of Pila's souvenirs was probably not high enough. Pila made a mid-price souvenir with poor design that did not convince souvenir shops, neither tourists. Pila's decision to publicize the social component did not have any significant impact.

\section{Market research}

When the idea of a youth hostel came into Icaria's management team minds, the first thing they did was to do a serious market research. At that time Barcelona Ryanair had recently acquired the license to operate in Barcelona airport increasing the number of tourists with a low budget to spend. Icaria took that into account and also studied the number of beds available in the city, the price range, average stay in the city, average expenditure, etc... The local government also confirmed that there was a real need for low-budget hotels, specifically for youth. There was a clear market demand for their product before they started investing in building the Youth Hostel. 
At Pila's, the management team decided to do something in the area of tourism following the same reasoning as Icaria, tourism was flourishing in Barcelona and was expected to be one of the main sources of revenue for the city. As one of the employees had some knowledge in pottery handicrafts they matched this know-how with the idea of tourism and decided to do pottery souvenirs. They did not perform any market research and did not find out that the demand was rather scarce once they had already invested in an oven and trained some of the employees.

\section{Network}

Another critical factor for the success of Icaria's innovation was the stakeholder involvement they achieved and the network they built around their new idea. Besides involving all management team, employees, employees' families and the Taiga school, Icaria team managed to successfully involve the local government, other city hotels and several other institutions that collaborated greatly on the success of Inout. The small hotel in Switzerland opened its doors to Icaria team and offered them some advice and training. The local government encouraged Icaria to build a youth hostel and gave them the building at a very advantageous condition. Other hotels of Barcelona city also collaborated with Icaria by offering old furniture for free. The network was created before, during and after the youth hostel was opened and helped Inout tremendously.

Pila did receive support from employees and families that trusted the management team and accepted all of its decisions. However, they did not have the support of tourism information points, museums, local government or any institution that could help them place their products once launched in the market.

\section{Social need pressure}

Icaria was more compelled to innovate faster than Pila. The fact that Icaria had a school, Taiga, whose students once finishing studies automatically had a job in Icaria's printing business added a pressure that Pila did not have. Icaria had to increase the number of employees while Pila had enough with maintaining it. Furthermore, Icaria had to accept new employees every year, while Pila had the choice to send some of them to early retirement.

We therefore define social need pressure as the strain or tension felt by the management team when they feel there is high urgency to solve or mitigate a social need. 
In this case, high social need pressure motivated Icaria to think harder and faster about a solution to the situation they were facing.

\section{Managerial trust on employees}

Before the organizational changes were made, employees at both Icaria and Pila performed similar tasks: labor intensive tasks, repetitive and structured. And moreover, it appeared that all people with mental disabilities in the world did similar type of jobs. It was natural to think that this type of job was the only type to be performed by people with mental disabilities. That is exactly what Pila's management team thought. When brainstorming about new products or business they could come in to innovate and increase their sources of revenues. However, they always thought that it had to be something that "their employees could do" which in reality meant "something similar to what their employees were currently doing". This idea very much constrained Pila's innovation alternatives.

Icaria's team had much higher trust on their employees' capabilities. Although their employees had never performed any job in the services sector, even less a job where they had to be in the front office directly interacting with the clients or a job that required some basic knowledge of different languages, managers believed everyone could be trained and any job could be performed by their employees. This way of thinking opened the range of possible business model innovations that could be considered.

\section{Conclusions}

In this paper we have examined two work integration social enterprises in the field of tourism and hospitality. Both firms undertook a business model innovation in order to overcome a severe crisis that compromised their economic and social impact. By comparing both cases, with different performance results, we have been able to identify several critical factors that influenced the success of the social business model innovation.

Some factors like value proposition, appropriate market research and network and stakeholder involvement were already identified in previous academic works. Our contribution has been twofold, first, we have corroborated that the aforementioned factors were indeed critical. Second, we have added two new factors into consideration named 
social need pressure and managerial trust on employees. We believe these factors greatly determined the ability of reinventing their business structure.

The selection of a case-based approach allows for an in-depth knowledge of the companies studied but it also entails some limitations so further research on the factors that help explain business model innovation in social enterprises is needed.

Due to the lack of research in the area, this paper can contribute to enlarge the current state of the art on both social business and business model literature and have some relevant managerial implications.

\section{References}

Afuah, A. 2004, "Business models: A strategic management approach", McGraw-Hill, pp.448. ISBN: 0072883642 .

Allan, B. 2005, "Social enterprise: through the eyes of the consumer (prepared for the National Consumer Council)", Social Enterprise Journal, vol. 1, no. 1, pp. 57-77.

Austin, J., Stevenson, H. \& Wei-Skillern, J. 2006, "Social and Commercial Entrepreneurship: Same, Different, or Both?", Entrepreneurship: Theory \& Practice, vol. 30, no. 1, pp. 1-22.

Baden-Fuller, C. \& Morgan, M.S. 2010, "Business models as models", Long range planning, vol. 43 , no. 2 , pp. 156-171.

Battilana, J. \& Dorado, S. 2010, Building Sustainable Hybrid Organizations: the Case of Commercial Microfinance Organizations, Academy of Management.

Bessant, J. \& Tidd, J. 2007, Innovation and entrepreneurship, John Wiley \& Sons.

Boons, F. \& Lüdeke-Freund, F. 2013, "Business models for sustainable innovation: stateof-the-art and steps towards a research agenda", Journal of Cleaner Production, vol. 45, pp. 9-19.

Bornstein, D. 2004, How to change the world: Social entrepreneurship and the power of ideas. Oxford University Press, Oxford, England.

Borzaga, C. \& Defourny, J. 2001, The Emergence of Social Enterprise. Routledge, London and New York.

Borzaga, C. \& Solari, L. 2001, "Management Challenges for Social Enterprises" in The Emergence of Social Enterprise, eds. C. Borzaga \& J. Defourny, Routledge, London, England. 
Cajaiba-Santana, G. 2013, "Social innovation: Moving the field forward. A conceptual framework", Technological Forecasting and Social Change, Handbook of Research on Social Entrepreneurship, Edward Elgar Publishing, Ed. Fayolle, A. \& Matlay, H.

Chell, E., Nicolopoulou, K. \& Karataş-Özkan, M. 2010, "Social entrepreneurship and enterprise: International and innovation perspectives", Entrepreneurship \& Regional Development, vol. 22, no. 6, pp. 485-493.

Chesbrough, H. 2010, "Business model innovation: opportunities and barriers", Long range planning, vol. 43 , no. 2 , pp. 354-363.

Chesbrough, H. \& Rosenbloom, R.S. 2002, "The role of the business model in capturing value from innovation: evidence from Xerox Corporation's technology spin-off companies", Industrial and corporate change, vol. 11, no. 3, pp. 529-555.

Crossan, M.M. \& Apaydin, M. 2010, "A Multi-Dimensional Framework of Organizational Innovation: A Systematic Review of the Literature", Journal of Management Studies, vol. 47, no. 6, pp. 1154-1191.

Dacin, T., Dacin, P.A. \& Tracey, P. 2011, "Social Entrepreneurship: A Critique and Future Directions", Organization Science, vol. 22, no. 5, pp. 1203-1213.

Dawson, P. \& Daniel, L. 2010, "Understanding social innovation: a provisional framework", International Journal of Technology Management, vol. 51, no. 1, pp. 921.

Demil, B. \& Lecocq, X. 2010, "Business model evolution: in search of dynamic consistency", Long range planning, vol. 43, no. 2, pp. 227-246.

Drayton, W. 2002, "The Citizen Sector: Becoming as entrepreneurial and competitive as business.", California management review, vol. 44, no. 3, pp. 120-132.

Easterly, L. \& Miesing, P. 2007, "Social venture business strategies for reducing poverty",Business and Society, vol. 48 no. 4 538-564, pp. 3-26.

Eisenhardt, K.M. 1989, "Building Theories from Case Study Research", Academy of Management Review, vol. 14, no. 4, pp. 532-550.

Eisenhardt, K.M. \& Graebner, M.E. 2007, "Theory Building from Cases: Opportunities and Challenges", Academy of Management Journal, vol. 50, no. 1, pp. 25-32.

Hamel, G. 2000, "Leading the Revolution ", Harvard Business School Press, Boston, MA, USA, .

Harvey, C., Maclean, M., Gordon, J. \& Shaw, E. 2011, "Andrew Carnegie and the foundations of contemporary entrepreneurial philanthropy", Business History, vol. 53, no. 3, pp. 425-450.

Hruschka, D.J., Schwartz, D., Cobb St.John, D., Picone-Decaro, E., Jenkins, R.A. \& Carey, J.W. 2004, "Reliability in Coding Open-Ended Data: Lessons Learned from HIV Behavioral Research ", Field Methods, vol. 16, pp. 307-331.

Johnson, M.W. 2010, "Seizing the white space: Business model innovation for growth and renewal", Harvard Business Press. 
Konczal, E.F. 1975, "Models are for managers, not mathematicians", Journal of Systems Management, vol. 26, no. 165, pp. 12-15.

Mair, J. \& Schoen, O. 2005, "Social entrepreneurial business models: an exploratory study", IESE Working Paper, no. 610, October 2005, available at: http://papers.ssrn.com/sol3/papers.cfm?abstract_id=875816 (accessed 15 April 2014).

Mair, J. \& Martí, I. 2006, "Social entrepreneurship research: A source of explanation, prediction, and delight", Journal of World Business, vol. 41, no. 1, pp. 36-44.

Mair, J. \& Schoen, O. 2007, "Successful social entrepreneurial business models in the context of developing economies: An explorative study", International Journal of Emerging Markets, vol. 2, no. 1, pp. 54-68.

Markides, C. \& Charitou, C.D. 2004, "Competing with dual business models: A contingency approach", The Academy of Management Executive, vol. 18, no. 3, pp. 2236.

Márquez, P.C., Reficco, E., Berger, G. \& Network, S.E.K. 2010, Socially inclusive business: Engaging the poor through market initiatives in Iberoamerica, Harvard University, David Rockfeller Center for Latin American Studies and Inter-American Development Bank.

Merton, R.K., Fiske, M. \& Kendall, P.L. 1990, The Focused Interview: A Manual of Problems and Procedures, 2nd Ed. edn, Free Press, New York.

Michelini, L. 2012, "Corporate Social Entrepreneurship and New Business Models", in Michelini, L. (Ed.), Social Innovation and New Business Models, Springer Berlin Heidelberg, pp. 19-35.

Michelini, L. \& Fiorentino, D. 2012, "New business models for creating shared value", Social Responsibility Journal, vol. 8, no. 4, pp. 561-577.

Miles, M.B. \& Huberman, A.M. 1994, Qualitative data analysis: an expanded sourcebook, 2nd edition edn, Sage Publications.

Mitchell, D. \& Coles, C. 2003, "The ultimate competitive advantage of continuing business model innovation", Journal of Business Strategy, vol. 24, no. 5, pp. 15-21.

Mulgan, G. 2006, "The Process of Social Innovation", Innovations: Technology, Governance, Globalization, vol. 1, no. 2, pp. 145-162.

Nicholls, A. 2006, "Introduction: The meanings of social entrepreneurship." in Social entrepreneurship: New paradigms for sustainable social change, ed. A. Nicholls, Oxford University Press, Oxford, pp. 1-36.

Osterwalder, A. \& Pigneur, Y. 2010, "Business model generation: a handbook for visionaries, game changers, and challengers", John Wiley \& Sons Inc., Hoboken, New Jersey.

Phills, J.A., Deiglmeier, K. \& Miller, D.T. 2008, "Rediscovering social innovation", Stanford Social Innovation Review, vol. 6, no. 4, pp. 34-43. 
Pol, E. \& Ville, S. 2009, "Social innovation: Buzz word or enduring term?", The Journal of Socio-Economics, vol. 38, no. 6, pp. 878-885.

Rajgopal, S., Venkatachalam, M. \& Kotha, S. 2003, "The value relevance of network advantages: The case of e-commerce firms", Journal of Accounting Research, vol. 41, no. 1 , pp. 135-162.

Ries, E. 2011, "The lean startup: How today's entrepreneurs use continuous innovation to create radically successful businesses", Crown Publishing Group, New York.

Sawhney, M., Wolcott, R.C. \& Arroniz, I. 2011, "The 12 different ways for companies to innovate", Top 10 Lessons on the New Business of Innovation, vol. 47, pp. 28.

Shafer, S.M., Smith, H.J. \& Linder, J.C. 2005, "The power of business models", Business horizons, vol. 48, no. 3, pp. 199-207.

Sinkovics, N., Sinkovics, R.R. \& Yamin, M. 2014, "The role of social value creation in business model formulation at the bottom of the pyramid-Implications for MNEs?", International Business Review, http://dx.doi.org/10.1016/j.ibusrev.2013.12.004.

Spear, R. \& Bidet, E. 2005, "Social enterprise for work integration in 12 european countries: a descriptive analysis", Annals of Public \& Cooperative Economics, vol. 76, no. 2, pp. 195-231.

Stoner, J.A.F. \& Wankel, C. 2007, "Innovative Approaches to Reducing Global Poverty". IAP, New York.

Teece, D.J. 2010, "Business models, business strategy and innovation", Long range planning, vol. 43, no. 2, pp. 172-194.

Thompson, J.D. \& MacMillan, I.C. 2010, "Business models: Creating new markets and societal wealth", Long range planning, vol. 43, no. 2, pp. 291-307.

Thompson, J. \& Doherty, B. 2006, "The diverse world of social enterprise: A collection of social enterprise stories", International Journal of Social Economics, vol. 33, no. 5/6, pp. 361-375.

von der Weppen, J. \& Cochrane, J. 2012, "Social enterprises in tourism: an exploratory study of operational models and success factors", Journal of Sustainable Tourism, vol. 20, no. 3, pp. 497-511.

Yunus, M. 2008, Creating a world without poverty: Social business and the future of capitalism. Public Affairs, New York.

Yunus, M., Moingeon, B. \& Lehmann-Ortega, L. 2010, "Building social business models: lessons from the Grameen experience", Long range planning, vol. 43, no. 2, pp. 308325.

Zott, C., Amit, R. \& Massa, L. 2011, "The business model: recent developments and future research", Journal of management, vol. 37, no. 4, pp. 1019-1042. 


\section{List of Tables}

Table 1. Literature review on the definition of business models.

\begin{tabular}{|l|l|}
\hline Authors & Definition \\
\hline $\begin{array}{l}\text { Casadesus-Masanell } \\
\text { and Ricart (2011) }\end{array}$ & $\begin{array}{l}\text { A set of managerial choices and the consequences of those } \\
\text { choices }\end{array}$ \\
\hline Amit and Zott (2010) & $\begin{array}{l}\text { A system of independent activities that transcends the local } \\
\text { firms and span its boundaries }\end{array}$ \\
\hline $\begin{array}{l}\text { Osterwalder et al. } \\
(2005)\end{array}$ & $\begin{array}{l}\text { A conceptual tool containing a set of objects, concepts and } \\
\text { their relationships with the objective to express the business } \\
\text { logic of a specific firm }\end{array}$ \\
\hline Shafer et al. (2005) & $\begin{array}{l}\text { A representation of a firm's underlying core logic and } \\
\text { strategic choices for creating and capturing value within a } \\
\text { value network }\end{array}$ \\
\hline Zott and Amit (2001) & $\begin{array}{l}\text { The content, structure, and governance of transactions } \\
\text { designed so as to create value through the exploitation of } \\
\text { business opportunities }\end{array}$ \\
\hline
\end{tabular}


Table 2. Literature review on business model components.

\begin{tabular}{|c|c|}
\hline Authors & Business model components \\
\hline $\begin{array}{l}\text { Casadesus-Masanell } \\
\text { and Ricart (2011) }\end{array}$ & Policy choices, asset choices, governance choices \\
\hline $\begin{array}{l}\text { Osterwalder and } \\
\text { Pigneur (2010) }\end{array}$ & $\begin{array}{l}\text { Customer segments, value propositions, channels, customer } \\
\text { relations, revenue streams, key resources, key activities, key } \\
\text { partnerships, cost structure }\end{array}$ \\
\hline Yunus et al. (2010) & $\begin{array}{l}\text { Value proposition (stakeholders and product/service), social } \\
\text { profit equation (social profit and environmental profit), value } \\
\text { constellation (internal value chain and external value chain) } \\
\text { and economic profit equation (sales revenues, cost structure, } \\
\text { and capital employed) }\end{array}$ \\
\hline Zott and Amit (2010) & $\begin{array}{l}\text { Design elements (content, structure, governance) and design } \\
\text { themes (novelty, lock-in, complementarities, efficiency) }\end{array}$ \\
\hline Rasmussen (2007) & $\begin{array}{l}\text { Value proposition, market segment and revenue model, value } \\
\text { chain, cost structure and profit potential, value network, } \\
\text { competitive strategy }\end{array}$ \\
\hline $\begin{array}{l}\text { Osterwalder et al. } \\
(2005)\end{array}$ & $\begin{array}{l}\text { Value proposition, distribution channel, relationship with } \\
\text { customers, partner network and revenue model }\end{array}$ \\
\hline Shafer et al. (2005) & $\begin{array}{l}\text { Strategic choices, creating value, capturing value, and the } \\
\text { value network }\end{array}$ \\
\hline $\begin{array}{l}\text { Hedman and Kalling } \\
\text { (2003) }\end{array}$ & $\begin{array}{l}\text { Customers, competitors, offering, activities and organization } \\
\text { resources, supply of factor and production inputs, } \\
\text { longitudinal process component }\end{array}$ \\
\hline $\begin{array}{l}\text { Chesbrough and } \\
\text { Rosenbloom (2002) }\end{array}$ & $\begin{array}{l}\text { value proposition, market segment, structure of the value } \\
\text { chain, cost and profit structure, position of the firm within } \\
\text { the value network context, competitive strategy }\end{array}$ \\
\hline $\begin{array}{l}\text { Gordijn and } \\
\text { Akkermans (2001) }\end{array}$ & $\begin{array}{l}\text { Value in, value port, actor, value activity, value exchange, } \\
\text { value object, profitability calculation }\end{array}$ \\
\hline Hamel (2000) & $\begin{array}{l}\text { Core strategy, strategic resources, customer interface and } \\
\text { value network }\end{array}$ \\
\hline
\end{tabular}


Table 3. Summary description of cases

\begin{tabular}{|c|c|c|}
\hline & Icaria & Pila \\
\hline Founding year & 1992 & 1991 \\
\hline Original business activity & Printing & Assembly \\
\hline Total number of employees in 2008 & 40 & 31 \\
\hline $\begin{array}{l}\text { Number of employees with disability } \\
\text { in } 2008\end{array}$ & 32 & 24 \\
\hline Disability of employees & Mental disability & Mental disability \\
\hline Profit distribution & Non-profit & Non-profit \\
\hline CEO characteristics & $\begin{array}{l}\text { CEO also founder } \\
\text { Teacher } \\
\text { Age: } 58 \\
\text { Female }\end{array}$ & $\begin{array}{l}\text { CEO also founder } \\
\text { Engineer } \\
\text { Age: } 54 \\
\text { Male }\end{array}$ \\
\hline
\end{tabular}

Table 4. Changes in Icaria

\begin{tabular}{|c|c|c|}
\hline & 2004 & 2013 \\
\hline Business Activity & Printing & Youth Hostel \\
\hline Social objective & $\begin{array}{l}\text { Provide jobs to people with } \\
\text { disabilities }\end{array}$ & $\begin{array}{l}\text { Provide jobs to people with } \\
\text { disabilities }\end{array}$ \\
\hline Type of business & $\mathrm{B} 2 \mathrm{~B}$ & $\mathrm{~B} 2 \mathrm{C}$ \\
\hline Partners & Taiga School & $\begin{array}{c}\text { Taiga School } \\
\text { Local government } \\
\text { City hotels } \\
\text { International associations }\end{array}$ \\
\hline Value proposition & $\begin{array}{c}\text { Quality } \\
\text { Flexibility }\end{array}$ & $\begin{array}{l}\text { Convenient, cheap and clean } \\
\text { stay } 20 \text { min from the city center }\end{array}$ \\
\hline Clients & $\begin{array}{c}\text { Loyal clients } \\
\text { Mainly local institutions }\end{array}$ & $\begin{array}{c}\text { Young and international } \\
\text { tourists }\end{array}$ \\
\hline
\end{tabular}

Table 5: Changes in Pila

\begin{tabular}{|l|c|c|}
\hline & $\mathbf{2 0 0 4}$ & $\mathbf{2 0 1 3}$ \\
\hline Business Activity & $\begin{array}{c}\text { Assembly of electronic } \\
\text { components }\end{array}$ & $\begin{array}{c}\text { Creation and assembly of } \\
\text { jewelry and souvenirs }\end{array}$ \\
\hline Social objective & $\begin{array}{c}\text { Provide jobs to people with } \\
\text { disabilities }\end{array}$ & $\begin{array}{c}\text { Provide jobs to people with } \\
\text { disabilities }\end{array}$ \\
\hline Type of business & B2B & B2B and B2C \\
\hline Partners & Families & $\begin{array}{c}\text { Families } \\
\text { Employees }\end{array}$ \\
\hline Value proposition & $\begin{array}{c}\text { Quality } \\
\text { Flexibility (small orders) } \\
\text { Closeness to client }\end{array}$ & $\begin{array}{c}\text { Social } \\
\text { Ecological }\end{array}$ \\
\hline Clients & $\begin{array}{c}\text { Only two big clients } \\
\text { loyal }\end{array}$ & $\begin{array}{c}\text { Many small clients } \\
\text { Price-sensitive }\end{array}$ \\
\hline
\end{tabular}

